\title{
KONDISI SELF DISCLOSURE MAHASISWA BIMBINGAN DAN KONSELING
}

\author{
Gusmawati $^{1}$, Taufik $^{2}$, Ifdil ${ }^{3}$ \\ *) Jurusan Bimbingan dan Konseling, Fakultas Ilmu Pendidikan, Universitas Negeri Padang
}

\begin{abstract}
Abstrak
Penelitian ini bertujuan untuk mengidentifikasikan kondisi self disclosure mahasiswa Bimbingan dan Konseling berdasarkan dimensi keluasan dan kedalaman. Jenis penelitian ini adalah penelitian deskriptif dengan metode kuantitatif. Instrumen yang digunakan adalah Inventori Pengukuran Self Disclosure Mahasiswa (IPSDM), dengan Sampel sebanyak 85 orang mahasiswa menggunakan teknik Simple Random Sampling. Temuan penelitian mengungkapkan bahwa, 1) Sebanyak 55,29\% mahasiswa Bimbingan dan Konseling memiliki kondisi keluasan self disclosure pada kategori tidak luas dan dilihat pada target person menunjukkan bahwa ibu merupakan target person pertama dan paling banyak dipilih responden penelitian $(72,16 \%)$, 2) Sebanyak 38,82\% mahasiswa Bimbingan dan Konseling memiliki kondisi kedalaman self disclosure pada kategori sedang. Penelitian ini merekomendasikan mahasiswa Bimbingan dan Konseling, agar dapat memperluas dan memperdalam kemampuan melakukan self disclosure dan perlu pelayanan Bimbingan dan Konseling untuk memperluas dan memperdalam kemampuan dalam melakukan self disclosure.
\end{abstract}

Keyword: Self disclosure, Mahasiswa

Copyright (C) 2016 IICET (Padang - Indonesia) - All Rights Reserved Indonesian Institute for Counseling, Education and Theraphy(IICET)

\section{PENDAHULUAN}

Hubungan antar pribadi yang sehat ditandai oleh keseimbangan pengungkapan diri atau self disclosure yang tepat. Self disclosure yaitu saling memberikan data biografis, gagasan-gagasan pribadi, dan perasaanperasaaan yang tidak diketahui bagi orang lain, dan umpan balik berupa verbal dan respon-respon fisik kepada orang dan/ atau pesan-pesan mereka di dalam suatu hubungan (Budyatna, M \& Ganiem, L. M, 2011: 40). Mahasiswa Bimbingan dan Konseling sangat memerlukan self disclosure dalam proses konseling yang dilakukannya. Wisnuwardhani, D \& Mashoedi, S. F (2012: 50) menyatakan bahwa pada umumnya self disclosure bersifat saling berbalas (reciprocal) dan menurut Dindia (dalam Wisnuwardhani, D \& Mashoedi, S. F, 2012: 50) bila konselor terbuka maka akan menstimulasi klien untuk juga terbuka. Dengan keterbukaan tersebut maka permasalahan yang dikemukakan dalam konseling dapat teratasi.

Selain itu Wrightsman (dalam Hidayat, D, 2012: 106) menjelaskan bahwa pengungkapan diri (self disclosure) adalah proses menghadirkan diri yang diwujudkan dalam kegiatan membagi perasaan dan informasi dengan orang lain. Dapat disimpulkan bahwa self disclosure merupakan proses berbagi yang dilakukan oleh seseorang kepada orang lain tentang berbagai hal dan informasi yang terkait dirinya dalam bentuk komunikasi.

Berdasarkan penelitian Sari, R. P, dkk (2010: 21) terhadap 346 orang mahasiswa tahun pertama, didapatkan hasil pengungkapan diri (self disclosure) mahasiswa hanya berada pada kategori rendah sampai sedang dan pengungkapan diri mahasiswa pria lebih rendah dari mahasiswa wanita. Selanjutnya dari penelitian yang dilakukan oleh Ifdil, dkk (2013) diperoleh hasil bahwa 29\% mahasiswa berada dalam kategori tingkat self disclosure sedang dan 36,2\% mahasiswa berada dalam kategori tingkat self disclosure rendah.

Hasil observasi yang peneliti lakukan selama perkuliahan, didapati bahwa mahasiswa Bimbingan dan Konseling cenderung kesulitan dalam membuka diri. Diantaranya ada yang tidak mau bercerita tentang diri dan kehidupan mereka sendiri kepada teman sesama mahasiswa, ada diantara mereka yang menutup diri dalam pergaulan sehingga hanya berteman dengan orang sama dari waktu ke waktu, ada juga yang ketika memiliki masalah memilih untuk menyendiri dan hanya dapat terbuka dalam kelompok tertentu misalnya ada

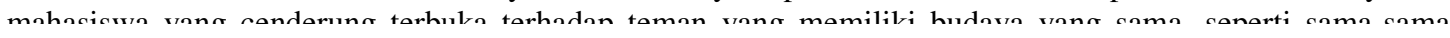


Selanjutnya dari hasil studi awal, didapatkan hasil bahwa delapan dari dua belas orang mahasiswa tersebut kesulitan dalam melakukan pengungkapan diri (self disclosure) dengan berbagai pertimbangan, diantaranya ada yang takut berkonsultasi dengan dosen pembimbing terkait masalah yang dialami dalam proses perkuliahan, ada yang takut dicemoohkan teman, takut teman tidak dapat menerima kondisi yang sebenarnya dan berbagai alasan lainnya.

\section{METODELOGI PENELITIAN}

Penelitian ini menggunakan metode kuantitatif dengan pendekatan deskriptif. Populasi penelitian adalah seluruh mahasiswa Bimbingan dan Konseling yang terdaftar pada tahun ajaran 2015/2016 dengan perolehan sampel sebanyak 85 orang dengan penarikan sampel dalam penelitian menggunakan simple random sampling. Data dianalisis dengan menggunakan teknik analisis deskriptif dan kemudian ditetapkan kriteria penetapan masing-masing data yang diperoleh dengan menggunakan mean hypothetic.

\section{HASIL DAN PEMBAHASAN PENELITIAN}

Berdasarkan pengolahan data maka dikemukakan hasil penelitian sebagai berikut,

1. Keluasan self disclosure mahasiswa Bimbingan dan Konseling

Gambaran keluasan self disclosure mahasiswa Bimbingan dan Konseling dapat dilihat pada tabel 1 berikut,

Tabel 1

Kondisi Keluasan Self Disclosure Mahasiswa

Bimbingan dan Konseling Secara Umum

$\mathbf{n}=\mathbf{8 5}$

\begin{tabular}{|l|l|c|c|c|}
\hline No & Kategori & Interval Skor & $\mathbf{f}$ & \% \\
\hline 1 & Luas & $\geq 26$ & 6 & 7,06 \\
\hline 2 & Sedang & $\geq 16 \mathrm{~s} / \mathrm{d}<26$ & 32 & 37,65 \\
\hline 3 & Tidak Luas & $<16$ & 47 & 55,29 \\
\hline
\end{tabular}

Data pada tabel 1 menampilkan kondisi keluasan self disclosure mahasiswa Bimbingan dan Konseling secara umum. Sebanyak 55,29\% mahasiswa memiliki kondisi keluasan self disclosure pada kategori tidak luas, sebanyak 37,65\% mahasiswa memiliki kondisi keluasan self disclosure pada kategori sedang, dan sebanyak 7,06\% mahasiswa memiliki kondisi keluasan self disclosure pada kategori luas. Hal ini menunjukkan bahwa kondisi keluasan self disclosure mahasiswa Bimbingan dan Konseling pada umumnya berada pada ketegori tidak luas. berikut,

Selanjutnya keluasan self disclosure yang dilihat dari target person terpapar pada gambar 1

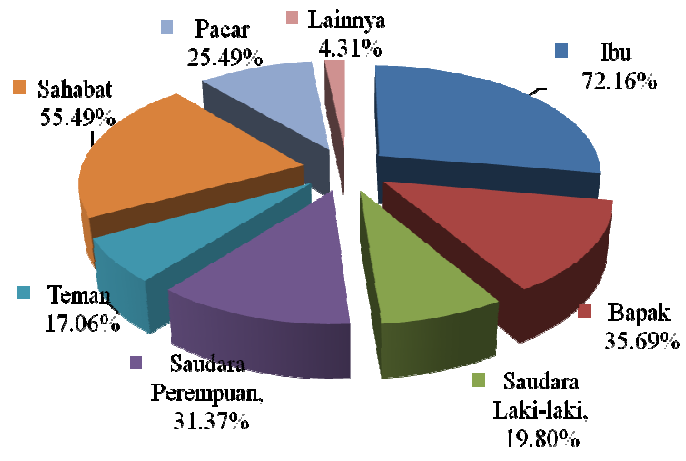

Gambar 1. Target person self Disclosure Mahasiswa Bimbingan dan Konseling

Data pada gambar 1 menunjukkan secara keseluruhan perolehan dari target person mahasiswa Bimbingan dan Konseling dalam melakukan self disclosure. Sebanyak 72,16\% mahasiswa memilih target person Ibu yang menunjukkan bahwa ibu merupakan target person pertama dan terbanyak dipilih oleh mahasiswa Bimbingan dan Konseling dalam melakukan self disclosure, selanjutnya peringkat kedua sebanyak 55,49\% mahasiswa memilih Sahabat sebagai target person, yang ketiga sebanyak 35,69\% mahasiswa memilih target person Bapak. 
Hasil penelitian menunjukkan bahwa kondisi keluasan self disclosure mahasiswa Bimbingan dan Konseling pada umumnya berada pada ketegori tidak luas dan ibu merupakan target person pertama dan paling banyak dipilih oleh mahasiswa Bimbingan dan Konseling. Hal tersebut menunjukkan bahwa mahasiswa Bimbingan dan Konseling belum mampu membuka diri kepada berbagai target person dan lebih terbuka kepada Ibu, karena Ibu merupakan sosok yang paling dekat dan paling dapat dipercaya. Sesuai dengan yang dikemukakan oleh Gainau, M. B (2009: 6), self disclosure yang dalam, diceritakan kepada orang-orang yang memiliki kedekatan hubungan (intimacy). Selanjutnya, Taylor, S. E, dkk (2012: 337) menyatakan, orang cenderung membuka informasi personal kepada orang yang dipercayainya.

Keluasan self disclosure mahasiswa Bimbingan dan Konseling jika dilihat dari masing-masing topik (a) Sikap dan opini, berada pada kategori sedang. (b) Selera dan Minat, (c) Pendidikan, (d) Keuangan, (e) Kepribadian, dan (f) Fisik, berada pada kategori tidak luas. Hal ini menunjukkan bahwa untuk topik sikap dan opini mahasiswa Bimbingan dan Konseling memiliki self disclosure lebih luas dibandingkan dengan topik-topik yang lain.

Hasil tersebut menunjukkan bahwa keluasan self disclosure mahasiswa Bimbingan dan Konseling tergantung dari topik yang dikemukakan. Jourard (dalam Ifdil, 2013: 113) mengemukakan bahwa seseorang dalam mengungkapkan diri perlu mengetahui isu/topik dari self disclosure yang akan disampaikan. Selanjutnya, Ifdil (2013: 112) mengemukakan keluasan berkaitan dengan siapa seseorang mengungkapkan dirinya (target person) seperti orang yang baru dikenal, teman biasa, orangtua/saudara dan teman dekat.

Sementara untuk target person pada masing-masing topik yaitu, (a) Sikap dan opini, memilih Sahabat sebagai target person dalam melakukan self disclosure. (b) Selera dan Minat, memilih Ibu sebagai target person dalam melakukan self disclosure. (c) Pendidikan, memilih Ibu sebagai target person dalam melakukan self disclosure. (d) Keuangan, memilih Ibu sebagai target person dalam melakukan self disclosure. (e) Kepribadian, memilih Sahabat sebagai target person dalam melakukan self disclosure. (f) Fisik, memilih Ibu sebagai target person dalam melakukan self disclosure.

Hal tersebut menunjukkan bahwa untuk masalah dalam hal sikap dan opini, dan juga kepribadian, mahasiswa Bimbingan dan Konseling memilih Sahabat sebagai target person dalam melakukan self disclosure. Sedangkan untuk masalah terkait selera dan minat, pendidikan, keuangan, dan fisik, mahasiswa Bimbingan dan Konseling Ibu sebagai taget person dalam melakukan self disclosure. Tergambar di sini, berbeda topik permasalahan berbeda juga target person-nya.

Hasil tersebut didukung oleh pendapat Gainau, M. B (2009: 2) yang menyatakan, umum dan khususnya individu menginformasikan dirinya tergantung kepada siapa yang hendak diajak bicara. Selanjutnya Wisnuwardhani, D \& Mashoedi, S. F (2012: 50) menyatakan bahwa seiring dengan semakin akrabnya sebuah hubungan, maka pengungkapan diri (self disclosure) akan semakin sering dan mendalam yang menandai kedekatan atau keintiman hubungan yang ada.

\section{Kedalaman self disclosure mahasiswa Bimbingan dan Konseling}

Berdasarkan kriteria pengolahan data yang telah dibuat, dapat digambarkan kondisi kedalaman self disclosure mahasiswa Bimbingan dan Konseling pada tabel 2 berikut,

Tabel 2

Kondisi Kedalaman Self disclosure Mahasiswa Bimbingan dan Konseling Secara Umum $\mathbf{n}=85$

\begin{tabular}{|c|l|c|c|c|}
\hline No & \multicolumn{1}{|c|}{ Kategori } & Interval Skor & $\mathbf{f}$ & \% \\
\hline 1 & Sangat Dalam & $\geq 179$ & 9 & 10,59 \\
\hline 2 & Dalam & $\geq 167 \mathrm{~s} / \mathrm{d}<179$ & 20 & 23,53 \\
\hline 3 & Sedang & $\geq 155 \mathrm{~s} / \mathrm{d}<167$ & 33 & 38,82 \\
\hline 4 & Rendah & $\geq 143 \mathrm{~s} / \mathrm{d}<155$ & 16 & 18,82 \\
\hline 5 & Sangat Rendah & $<143$ & 7 & 8,24 \\
\hline
\end{tabular}

Data pada tabel 2 menampilkan kedalaman kondisi self disclosure mahasiswa Bimbingan dan Konseling secara umum. Sebanyak 38,82\% mahasiswa memiliki kedalaman self disclosure pada kategori sedang, 23,53\% mahasiswa memiliki kedalaman self disclosure pada kategori dalam, 18,82\% mahasiswa memiliki kedalaman self disclosure pada kategori rendah, 10,59\% mahasiswa memiliki kedalaman self disclosure pada kategori sangat dalam, dan $8,24 \%$ mahasiswa memiliki kedalaman self disclosure pada 
kategori sangat rendah. Hal ini menunjukkan bahwa kedalaman kondisi self disclosure mahasiswa Bimbingan dan Konseling pada umumnya berada pada kategori sedang.

Hasil penelitian menunjukkan bahwa secara keseluruhan kebanyakan mahasiswa Bimbingan dan Konseling memiliki kedalaman kondisi self disclosure dalam kategori sedang. Hal tersebut membuktikan bahwa kemampuan mahasiswa Bimbingan dan Konseling untuk melakukan self disclosure berada pada kategori sedang.

Untuk melihat lebih rinci mengenai kondisi self disclosure mahasiswa Bimbingan dan Konseling, berikut akan dideskripsikan sesuai dengan enam topik yang telah diteliti dan ditetapkan sebagai indikator yaitu,

a. Untuk self disclosure sikap dan opini, kebanyakan mahasiswa berada pada kategori dalam.

b. Untuk self disclosure selera dan minat, pada umumnya berada pada kategori dalam.

c. Untuk self disclosure pendidikan, kebanyakan mahasiswa berada pada kategori rendah.

d. Untuk self disclosure keuangan, kebanyakan mahasiswa berada pada kategori sedang.

e. Untuk self disclosure kepribadian, kebanyakan mahasiswa berada pada kategori sedang.

f. Untuk self disclosure fisik, kebanyakan mahasiswa berada pada kategori sedang.

Pemaparan tersebut membukti-kan bahwa untuk self disclosure sikap dan opini, dan self disclosure selera dan minat, kebanyakan mahasiswa Bimbingan dan Konseling berada pada kategori dalam. Untuk self disclosure keuangan, self disclosure kepribadian, dan self disclosure fisik, kebanyakan mahasiswa Bimbingan dan Konseling berada pada kategori sedang. Sedangkan untuk self disclosure pendidikan, kebanyakan mahasiswa Bimbingan dan Konseling berada pada kategori rendah.

Terlihat bahwa, kondisi self disclosure mahasiswa Bimbingan dan Konseling dipengaruhi oleh inikator atau topik permasalahan yang diceritakan. Berbeda topik permasalahan berbeda pula kondisi self disclosure nya. Sehingga ada kalanya pada topik tertentu mahasiswa Bimbingan dan Konseling memiliki self disclosure yang dalam, ada kalanya memiliki self disclosure yang sedang dan ada kalanya juga memiliki self disclosure yang rendah.

Hal tersebut Menurut Devito, J. A (2011: 67) terjadi karena, seseorang akan lebih cenderung membuka diri (melakukan self disclosure) tentang topik tertentu dari pada topik yang lain. Artinya dalam melakukan self disclosure mahasiswa Bimbingan dan Konseling juga memperhatikan berbagai hal sehingga terdapat perbedaan dari kondisi self disclosure yang dilakukan sesuai dengan indikator atau topik permasalahan yang akan diungkapkan.

Mahasiswa Bimbingan dan Konseling yang nantinya akan menjadi seorang guru BK ataupun Konselor, perlu untuk meningkatkan kemam-puannya dalam melakukan self disclosure. Jourard (dalam Devito, J. A, 2011: 67) mengemukakan bahwa self disclosure (pengungkapan diri) merupakan faktor penting dalam konseling dan psikoterapi. Jourard juga mengatakan bahwa seseorang mungkin membutuhkan bantuan konseling dan psikoterapi karena orang tersebut tidak pernah sebelumnya melakukan self disclosure (membuka diri kepada orang lain) secara memadai.

Kemampuan self disclosure mahasiswa Bimbingan dan Konseling nantinya akan sangat mempengaruhi proses konseling yang akan dilakukan-nya. Mahasiswa Bimbingan dan Konseling yang memiliki self disclosure yang dalam, akan mampu menjalankan sesi konseling dengan baik, karena dalam proses konseling ada hubungan timbal balik. Menurut Wisnuwardhani, D \& Mashoedi, S. F (2012: 50), pada umumnya self disclosure bersifat saling berbalas (reciprocal), bila yang satu terbuka, maka akan menstimuasi yang lainnya untuk terbuka juga. Artinya jika mahasiswa Bimbingan dan Konseling memiliki self disclosure yang dalam maka akan mampu menstimulasi klien untuk melakukan self disclosure dalam proses konseling nantinya.

\section{LIMITASI PENELITIAN}

Pada prinsipnya, penelitian ini telah dilaksanakan dengan mengacu pada metode dan prosedur ilmiah. Namun, penelitian ini memiliki beberapa keterbatasan seperti berikut ini:

1. Penelitian ini tidak dapat digeneralkan kepada seluruh angkatan mahasiswa Bimbingan dan Konseling, karena keterbatasan. Namun secara khusus jumlah sampel sudah sesuai dengan prosedur penarikan sampel.

2. Sampel dalam penelitian ini tidak dibedakan berdasarkan tahun masuk, jenis kelamin maupun kompetensi yang dimiliki mahasiswa Bimbingan dan Konseling.

3. Fokus penelitian ini hanyalah pada dua dimensi dari self disclosure, yaitu keluasan dan kedalaman terkait enam topik dalam indikator penelitian, hal ini berarti belum semua aspek self disclosure mahasiswa yang diteliti. Perlu penelitian lebih lanjut untuk mengungkap aspek-aspek lain dari self disclosure, baik melihat perbedaannya, maupun melihat hubungannya dengan variabel lain. 


\section{KESIMPULAN DAN SARAN}

\section{KESIMPULAN}

Berdasarkan penelitian yang dilakukan maka dapat disimpulkan, sebagai berikut.

1. Keluasan self disclosure mahasiswa Bimbingan dan Konseling pada umumnya berada pada kategori tidak luas dan pada target person menunjukkan bahwa Ibu merupakan target person pertama yang banyak dipilih mahasiswa, target person kedua adalah Sahabat dan target person ketiga adalah Bapak. Jika dilihat dari segi topik yang disampaikan kondisi keluasan self disclosure mahasiswa Bimbingan dan Konseling terkait masalah sikap dan opini berada pada kategori sedang, sementara untuk lima topik lainnya yaitu, selera dan minat, pendidikan, keuangan, kepribadian dan fisik kondisi self disclosure berada pada kategori tidak luas.

2. Kedalaman self disclosure mahasiswa Bimbingan dan Konseling keba-nyakan berada pada kategori sedang. Kedalaman self disclosure mahasiswa Bimbingan dan Konseling berdasar-kan indikator yaitu,

a. Self disclosure terkait dengan sikap dan opini, kebanyakan mahasiswa berada pada kategori dalam, artinya terkait masalah sikap dan opini mahasiswa Bimbingan dan Konseling mampu melakukan self disclosure secara mendalam.

b. Self disclosure terkait dengan selera dan minat, kebanyakan mahasiswa berada pada kategori dalam, artinya terkait masalah selera dan minat mahasiswa Bimbingan dan Konseling mampu melakukan self disclosure secara mendalam.

c. Self disclosure terkait dengan pendidikan, kebanyakan mahasiswa berada pada kategori rendah, artinya terkait masalah pendidikan mahasiswa Bimbingan dan Konseling kurang mampu melakukan self disclosure secara mendalam.

d. Self disclosure terkait dengan keuangan, kebanyakan mahasiswa berada pada kategori sedang, artinya terkait masalah keuangan mahasiswa Bimbingan dan Konseling cukup mampu melakukan self disclosure secara mendalam.

e. Self disclosure terkait dengan kepribadian, kebanyakan maha-siswa berada pada kategori sedang, artinya terkait masalah kepribadian mahasiswa Bimbingan dan Konseling cukup mampu melaku-kan self disclosure secara mendalam.

f. Self disclosure terkait dengan fisik, kebanyakan mahasiswa berada pada kategori sedang, artinya terkait masalah fisik mahasiswa Bimbingan dan Konseling cukup mampu melakukan self disclosure secara mendalam.

\section{SARAN}

Berdasarkan hasil penelitian maka peneliti mengemukakan beberapa saran, sebagai berikut.

1. Ketua Jurusan Bimbingan dan Konseling, disarankan agar dapat menyelenggarakan kegiatan pelayanan Bimbingan dan Konseling untuk dapat memperluas dan memperdalam kemampuan self disclosure mahasiswa Bimbingan dan Konseling.

2. Mahasiswa Bimbingan dan Konseling, disarankan agar dapat memperluas dan memperdalam kemampuan melakukan self disclosure yang nantinya akan sangat berguna dalam profesi sebagai guru BK atau Konselor dimasa yang akan datang.

\section{DAFTAR PUSTAKA}

Budyatna, M \& Ganiem, L. M. (2011). Teori Komunikasi Antar Pribadi. Jakarta: Kencana Prenada Media Group.

Devito, J. A. (2011). Komunikasi Antar Manusia Edisi Kelima. Alih Bahasa: Ir. Agus Maulana, M.S.M. Tanggerang: Karisma Publishing Group.

Gainau, M. B. (2009). Keterbukaan Diri (Self Disclosure) siswa dalam perspektif budaya dan implikasinya dalam konseling. Jurnal Ilmiah Widya warta, 33(1), 95-12.

Hidayat, D. (2012). Komunikasi Antar Pribadi dan Medianya. Yoyakarta: Graha Ilmu.

Ifdil., Ardi, Z., Bariyyah, K., Hariko, R., \& Solina, W. (2013). Tingkat Self Disclosure Mahasiswa Bimbingan dan Konseling. Prosiding Konvensi Nasional BK XVIII. Denpasar Bali, 14 s.d 16 November 2013. Profesi Konseling Bermartabat dalam Masyarakat Multikultural dan Modern.

Ifdil, I. (2013). Konsep Dasar Self Disclosure dan Pentingnya Bagi Mahasiswa Bimbingan Dan Konseling. Pedagogi, 13(1), 110-117. 
Sari, R. P., Andayani, T. R., \& Masykur, A. M. (2010). Pengungkapan diri mahasiswa tahun pertama universitas diponegoro ditinjau dari jenis kelamin dan harga diri. Jurnal Psikologi Undip, 3(2), 11-25.

Taylor, S. E., Peplau, L. A., dan Sears, D. O. (2012). Psikologi Sosial Edisi Kedia Belas. Terjemahan Oleh Tri Wibowo B.S. Jakarta: Kencana Prenada Media Group.

Wisnuwardhani, D \& Mashoedi, S. F. (2012). Hubungan Interpersonal. Jakarta: Salemba Humanika. 